\title{
COMMUNITY RADIO ROLES AS PUBLIC SPHERE STRUGGLING ORANG RIMBA RIGHTS FROM BUKIT DUABELAS NATIONAL PARK JAMBI PROVINCE, INDONESIA
}

\author{
Muchlis Fuad ${ }^{1 *}$, Lubis Djuara P. ${ }^{2}$, Kinseng Rilus A. ${ }^{2}$, Lecturers \\ Aulia Tasman ${ }^{3}$, Professor \\ ${ }^{1}$ Faculty of Agriculture, University of Jambi, Indonesia \\ ${ }^{2}$ Graduate School of Bogor Agricultural University, Indonesia \\ ${ }^{3}$ Faculty of Economics and Business, University of Jambi, Indonesia \\ ${ }^{*}$ E-mail: fuadm orange@yahoo.co.id
}

\begin{abstract}
The objective of the research is analyzing the roles of alternative media of community radio in struggling public rights of Orang Rimba in Bukit Duabelas National Park-Jambi. It is done by using case study method and analyzed by using qualitative method. It is located at south of Bukit Duabelas National Park or administratively located at Bukit Suban Village, Air Hitam, Sarolangun regency Jambi province. The results of the research explain that Benor FM as community radio for Orang Rimba which has roles as facilitating media and public sphere for them in struggling freedom for stating public opinion and creating public plan. Practically, Benor FM formulates and states widely some of Orang Rimba bussiness which is often ignored by representation institute, like struggling in conservation effort, emansipatoris, dan struglling to get public rights.
\end{abstract}

\section{KEY WORDS}

Benor FM, alternative media, Orang Rimba, community radio, public sphere.

Communication patterns which is top down and no democracy, still be a general issue happened in Indonesia, especially in village area. Teh result of the research of national communication and information institute in 2002, as quoted by Rachmiatie (2005) stated, "group of mass category in Indonesia shows passive characteristics or as an acceptor only, consume an information with bad quality and quantity". Democration in communication aspect by using alternative media where every citizents has the same rights about information which expect can eliminate the domination between one to another and control the power which potentially make a forward and properous society as advices in opening of UUD 1945.

Community radio in Indonesia as part of alternative media should be seen as public sphere representation on certain grade. So, community radio can make a struggle to create freedom space to state and receive public opinion or to create public discourse. Community radio can create public discourse which is free frommodal bussiness and power or from ideology which may be distored social reality, it can be from external or internal.

Alternative media in communication has an important role in empowerment for some communities. Teh existance of community radio as democration form of communication in term of content and media owner which is hoped that can run the empowerment role. For Orang Rimba community in Bukit Duabelas National Park, this community radio was born to struggle public rights and some business which are often ignored. The existance is for struggling freedom space to state and receive public opinion which appears and be a community needs and create public discourse which is free from any business that is going to distored social reality in the middle of Orang Rimba community for creating independency and free them from marginal circle.

Based on the explanation above, so problem identification in this research can be identified and formulated in these research questions:

1. How is the history and the existance of Orang Rimba community radio in Bukit Duabelas National Park?

2. How is the role of community radio as public sphre in struggling Orang Rimba rights in Bukit Duabelas National Park? 


\section{METHODS OF RESEARCH}

The research was conducted with qualitative approach in critical paradigm with case study research strategy (Yin, 1989). The research sites was in the southern part of Bukit Duabelas National Park or administratively located in Air Hitam Subdistrict of Sarolangun Regency of Jambi Province. This region became the location of the Community Radio station of Orang Rimba Benor FM. The data collection in the research was conducted with several techniques in accordance with qualitative research approaches (Creswell 2010) that is: recording news text, indepth interview with radio activist Benor FM (NGO activist), radio announcer from Orang Rimba, Temenggung Orang Rimba, from the villagers supporting the Bukit Duabelas National Park, the Commissioner of KPID of Jambi Province and the office of Balai Bukit Duabelas National Park in Sarolangun. Indepth interviews are conducted by referring to key questions developed during interviews and discussions. Data and information are also obtained from observation of direct observation, documentation and materials of Radio Benor FM broadcasting as well as Focus Group Discussion (FGD). FGD were conducted to explore ideas and confirm the results of previous data collection to make the data more comprehensive and relevant to the research objectives.

The data collected were analyzed descriptively. Qualitative descriptive analysis is by giving a review or interpretation of the data obtained so that becomes more clear and meaningful. The steps are data reduction, presentation of data with charts and text, then drawing conclusions to reveal facts, circumstances, phenomena, variables and circumstances that occurred during the study took place.

\section{RESULTS AND DISCUSSION}

Radio Benor FM: Orang Rimba alternative media. Benor FM is Orang Rimba community radio which is innitiated by KKI WARSI, an NGO in Jambi that concern to conservation issues and Orang Rimba in jambi province. Benor FM is located on the hills at the south side of Bukit Duabelas National Park, bukit suban village air hangat sarolangun regency jambi province. By using booster and exciter, Benor FM can reach 10 to 20 kilometers from location of the station. Moreover, because of the topography condition of Bukit Duabelas National Park, not all of group of Orang Rimba got the media. There are only two group who can be reached by Benor FM, they are group of Tumenggung nggrip in kedundung muda and Tumenggung Tarip in semapu river, pakuhaji. To make easier Orang Rimba understanding, so the announcing materials are provided into two languages, they are Indonesian and Orang Rimba language.

By Benor FM, Orang Rimba share any informations. Not only sing Orang Rimba favourite song, the announcer also tell various information and news starting from 08.00 till 17.00 WIB. The content of information is of course chosen based on their needs, like the information of rubber, rattan, and fruits price. Then, there are also information about environment, forest damage, and health if there is an unwell person. The existance of Benor FM is also used to discuss about Orang Rimba's culture to introduce people about their tradition, like born or wedding ritual of Orang Rimba, and culture punnishment. This event is generally announced with Orang Rimba's special music as an effort to ban streotype of orang terang on Orang Rimba like happen now.

"We hope that this radio can be a campaign media for Orang Rimba and media to connect the society and government to Orang Rimba. We campaign that Orang Rimba is not as like as people imagine, like dirty, smelly, and so on. There we tell people that Orang Rimba has culture and rules like us. We socialized it in radio.» (interview with the founder of Benor FM).

Alternative media Benor FM radio in this research based on communication experiences which exist as communities needs for completing and struggling the bussiness which are marginalized. Hopefully, the existance of Benor FM can be information media to Orang Rimba group which stay in the jungle. Understadning how is Benor FM exist, operate, hold and struggle, not only understand a radio in general, but can understand a culture and social dynamic, economic and politic which happen in this country, in the real form of traditional community in Indonesia. 
Public sphere fights communication distorcy. Some studies about community media from critical perpective shows that local media in Indonesia may be a facilitator of power man in local level and be a politic communication facility (Awaludin, 2011), community radio can be a public democracy facilitation (Rachmiati, 2005), resistention of community radio as alternative media (Maryani 2007), government hegemony by community radio (eddiyono 2012) and the existance of community radio as an information agent in the village area (Yuliasari, et al, 2015). Related to local culture content on cummunity media, gotten local policy and local identity which are seen from psychology aspect (Ridwan 2007). Communication pattern which is up top down and no democracy still be a general issue happened in Indonesia, every citizents has the same rights about information which expect can eliminate the domination between one to another and control the power which potentially make a forward and properous society.

Benor FM as part of alternative media can be seen as public representation on certain level and make effort in creating freedom space to state and receive public opinion or to create public discourse. Community radio can create public discourse which is free frommodal bussiness and power or from ideology which may be distored social reality, it can be from external or internal from Orang Rimba.

All areas in our social life give us chance to create public opinion which is called as public sphere and all citizents principly may enter that kind of space (Hardiman, 2009). In that public sphere, citizents might have the same chances to participate and free from the domination and participate in taking decisions. If Habermas takes a chat prototype in coffee house (England) on 18 century, salon (Franch) and tichgesllschaften (Germany) as public sphere, nowadays altenative media like community radio can be said as public sphere. This condition explains that era of public sphere topic in term of face to face has been moved to media.

In Orang Rimba case, Benor FM becomes one of media for Orang Rimba community to have a process critically to realize emansipatoris society, society which are concious and be able to say tehmselves as autonomic individual and can free themselves from any domination, it is as a point of view from Habermas (1989) which stated that only power decidded by critical public discussion is a power which cann be rationalized. Discussion like this may be done in a free sensor and domination society only. Actually, thery are the private one. But their talks create a public, because not about their privacy which are talked, but bussiness in general without any forces.

In Orang Rimba community, before empowerment program exists by using radio as the instrument, most of them are deaf in facing unfairness. They have to be supported to be brave in asking and requiring their rights. The obstacle "culture" to keep a good relation needs media, when a critic can be said by using media (without known by other people) so it can avoid that people in an opened conflict with others or in a community.

Not only about culture, Benor FM as media is a new technology in Orang Rimba community. As a technology which is developed then becomes a new institute, so there is no group which has power in this intitute. As a new instituute which is build by conciousness for taking out community from information domination of dominant group, so the young of Orang Rimba can support Benor FM becomes an intitution which relatively free from domination and processed to be a public sphere as told by Habernas. Meanwhile, it is not meant that Benor FM can be out or fall being a new system which might bind human with its system. It can happen if Benor FM follows the patterns of mainstream media operation by all teh administrative rules, schedule, text production system, announcing standart and so on. If it is happened, so the power in community media unites with its community be weak because of the system loses the community bussiness.

Benor FM roles in struggling Orang Rimba rights. The existance of Benor FM can transform a public sphere be more ideal like idealized by Orang Rimba. In this place, Orang Rimba can communicate and share confuseness about social, politics, economics, culture and so on. An ideal public sphere which is tranformed in journalism form, hopefully to be a free space to people to state their act, idea, sight and critics about the surrounding.

1. Struggle in keeping the conservation:

For Orang Rimba, jungle is a house as live space and living source. Orang Rimba live dynamics can not be out from jungle. Jungle be the hold in living process, as a place to hunt, create traditional medicines, and use the jungle or forest product to be economics source in 
their live which becomes their identity in running several traditions and cultures, it is inherited by ancestors as guidance in their live. So every doing the discussion with Orang Rimba, they always give a message "tolong jago rimbo kami" or "please, keep our place." This message also be a concern in Benor FM.

In managing natural resources, Orang Rimba knows an area given, like hompongan, tanoh peranokon, rimba, ladang, sesap, belukor and benuaron. This areal given is a rotation of land using orderly and can be said as succeed system from their jungle. A place that is called rimba by them, processed as field to main course meals, then after it is left change becomes sesap. The concept of hompongan by Orang Rimba means border. Hompongan is in the form of field which connect one to another in Bukit Duabelas National Park line to avoid illegal logging action which is done by other people. Tanah penarokan or penarokan land is a land which has been chosen by wizard which is free from the devil who want to disturb and it is for pregnant woman. This land may not be used to open the field. Benuaron is a historical land from ancetors of Orang Rimba which full of fruity tree, like durian, kemang, rambutan and so on which exist in rimba. Each od Orang Rimba keeps it. This land is a common property, so that everyone can use it by taking the fruits based on the needs only. In the rimba also known sialang tree as a honeycomb nest. Orang Rimba will keep this tree and fights if there is illegal logging on the tree because it will threat the population of honeycomb and affect on the decrease of their economic source.

\section{Emancipatory struggling:}

Emancipatory ethics according to Habermas (1993) is really related to communication action that is an interaction form which is the succesfulness believe depend on two sides who interact for reaching agreement and understand each other, or relationship between subject and dialogist subject or not a relationship of mnologist. Dialogist communication has an active role, where all sides take other's role, so ideal role taking happened. On this communication, understand each other can be reached, so Habermas names it as communicative rationality (Suseno 2004).

In Orang Rimba context, where the existance is often seen negatively by other community make an emancipatory communication have to be struggled. Negative view from orang terang by saying Orang Rimba as "kubu" as an underestimate action for Orang Rimba. It is an example of how the position of Orang Rimba is not equal. They are assumed as a left behind, uncultured, uneducated, and anti social. On of the way to stop stupidity is by doing campaign about the importance of education for generation of Orang Rimba. Benor FM radio campaign bepelajorang intensively to Orang Rimba.

Dialogue which is developed by Benor FM radio explains Orang Rimba point of view on their generation's future which must be facilitated by education (school). Orang Rimba opinion implicitly give messages that Orang Rimba is starting to realize the importance of education. Stupidity because of can not read, write and count still be worst things for Orang Rimba. Critical thinking is also developed by a willing to cut the forest product which they sell. They are starting to realize, so they send message to their siblings or known as sanak to motivate them to be emancipatory, free from stupidity, not lef behind, and other negative view which underestimate Orang Rimba.

Misunderstanding which has been inherited from many years ago until now happened continuously and potentially react horizontal conflict and must be ended. For some group of people, Orang Rimba is often assumed as disturbance, moreever since the decrease of natural resources because of the forest condition which is more narrow. This condition causes fight for natural resources. It is usually ended by conflict and victims will be from orabg rimba's side. Giddens in modernity and self identity, it reminds how the emancipatory value is applied in economic value. According to him, emancipatory politic has a concern on invidual and group freedom from the things which can be obsracles for them to get better live chances. It involves two important elements, first the effort to remove disturbance and problem from the past, so possible to create transformative act to tge future, second it aims to solve the unallowed domination from individuals and certain group on other individuals and group. Benor FM radio is also assumed as strategic thing to make society accept the existance of Orang Rimba and be able to solve misunderstanding and negative view on Orang Rimba, build the equivalence to society to accept and live togeteher in an equal relationship without change any identity. 
It is important to be announced by Benor FM radio by using content which has persuasive message to people (orang terang) in order amit and receive the existance of Orang Rimba. Campaign by using radio connects communication between Orang Rimba and society arround to support them to know general social culture, then society also know how's Orang Rimba culture. By this campaign, hopefully general community can remove several negative view about Orang Rimba, then change the attitude and action which can admit and appreciate the existance of Orang Rimba, and they can live together in a harmony situation. In another side, this radio program also provides information about village people's life and general norms in tbe villages. So this radio program can help to decrease conflict both two sides which is often happened by accepting and admitting the existance of Orang Rimba in general norm without remove their identity and have an equal view about Orang Rimba.

As the ideal of Habermas, communication is truely a systematic relation. Communication is always happened between balanced side. Communicayion is not about power, but it is happened if two sides can be equal, admit and believe each other. Knowledge which is transferred by using alternative media can be emancipatory knowledge which press the importance of knowledge and technology as a tool for humanization process. The values include culture, independent democracy, social fairness, natural environment integration and human related to human's bussiness to increase Orang Rimba's position.

3. Stuggles to get public rights:

As stated by Habermas (1993), at the beginning public sphere identically with tradition of borjuis people, so this space is often been equal with coffee houses abd clubs. In the development, intelectual group appreciate this tradition by taking substantion process which is very egaliter in those coffe houses and clubs. Tbompson told that public sphere as idea meet space and place for individuals to do dialogue in local culture setting as equal participant in live dialogue. When it is moved to alternative media, this situation is not distorted, even it is more crowded. Alternative media has unlimited acess in public live, interact with several public business and use public spot like frequency spectrum. They may fill the frequency space, if it includes 3 components, they are public convenience, public interest and public neccesity.

Orang Rimba kid is being a Benor FM radio announcer when they go out from jungle, then they back with stories, about the decrease of rubber and rattan price, worst health condition, damage forest, burning forest and field and another problems which are faced by Orang Rimba in the forest. Problems of topography make Orang Rimba are difficult to access general facilitations which are needed to support their life. Important information relates to primary needs of Orang Rimba are announced in Benor FM radio.

Based on information told by prang rimva in Benor FM radio is usually responsed seriously. For example health officer directly visit and pick Orang Rimba up and bring them to puskesmas to get the medicines as soon as possible. They also do free helping to Orang Rimba. Because of theor coming, finally they are asked to give socialization about healthy. By havibg it will support Orang Rimba to use general healthy facilitation which are provided like nursewife. Radio program will also campaign about healthy life related to environment changes. Like antisipative way on diare, tbc, malaria which nowadays often happened to Orang Rimba. Besides, Benor FM also campaign the importance of society's role to help health services for Orang Rimba.

The less Orang Rimba to get general facilities and difficulty to get a fair proces of commodity, because market is controlled by tauke, it is also discussed in Benor FM, like part of commodity prices as materials. This program will also help to give information about alterbative market which give more benefits.

So Benor FM radio takes roles in struggling freefom space to state and receive public opinion and try to build public discourse which is free from modal bussiness and power or from ideology that will distore social reality which happened by struggling Orang Rimba right.

From the explanation above, it is relevant to be asked how is public sphere which is created by Benor FM radio? First, Benor FM radio as media is a public sphere in traditional community is different with habermas description. Benor FM radio exist in community scope with marginal condition in some aspects, like social, economics and politics. Meanwhile habermas describes who involved with in public sphere are intellectual group of society. Second, as media which has ideal to build public sphere in the community, in the process of Benor FM radio not only ace the dominant masters, but market competition from other media 
like tv and radio which start be owned by Orang Rimba and being a competitor for Benor FM radio. Third, public sphere which is built in Benor FM radio as media, beside fight the dominant of state and market, sometimes also face communication culture and malay society in Bukit Duabelas National Park. As society which still run traditional realtionship or strong culture, so they give a directed and opened critics, it is assumed as an unwell thing for orang terang.

\section{CONCLUSION}

As alternative media, Benor FM radio can be seen as public sphere representation to state and receive public opinion and build public discourse which is free from ideology which will distore social reality, from external or internal community of Orang Rimba.

As public sphere, Benor FM radio guarantee that there will be a tree discussion and opened and possible critical argumentation about several issues on Orang Rimba; keeping the forest, emancipatory bussiness and rights as citizents.

\section{REFERENCES}

1. Awaludin I. 2011. Media lokal dalam konstelasi komunikasi politik di daerah. Jurnal IImu Sosial dan IImu Politik. 14 (3): 297-316

2. Creswell, J. 2007. Qualitative Inquiry \& Research Design: Choosing Among Five Approaches, 2nd ed. California: Sage Publication

3. Eddyono AS. 2012. Radio Komunitas dan Kegagalannya sebagai Media Counter Hegemony (Studi Kasus Pada Radio Panaganti dan Angkringan di Yogyakarta. Journal Communication Spectrum. 2 (1): 13-29

4. Habermas 1993. The Structural Transformation of the Public Sphere. Massachussetts: MIT Press

5. Hardiman. 2009. Menuju Masyarakat Komunikatif, Ilmu, Masyarakat Politik\& Post Modernisme Menurut Jurgen Habermas. Yogyakarta: Kanisius

6. Maryani E. 2007. Resistensi komunitas melalui radio alternatif. Tinjauan kritis terhadap radio komunitas "Angkringan" sebagai media alternatif di Desa Timbulharjo, Kecamatan Sewon, Kabupaten Bantul Propinsi DIY. [disertasi]. Depok: Universitas Indonesia

7. Muchlis F, et al. 2016. Communicative Action in Maintaining of the Communal Right (Case Study in Orang Rimba Bukit in the Eastern Region Bukit Duabelas National Park, Jambi Province, Indonesia). Internatinal Journal of Research in Social Science. ISSN 2307-227X) Vol X: 1-7

8. Rachmiatie A. 2005. Keberadaan radio komunitas sebagai eskalasi demokratisasi komunikasi pada komunitas pedesaan di Jawa Barat. Jurnal Mediator. 6 (2): 215-226

9. Ridwan NA. 2007. Landasan Keilmuan Kearifan Lokal. Jurnal Studi Islam dan Budaya. 5 (1): $27-38$

10. Suseno FM. 2004. Dalam kata pengantar Buku Kritik Ideologi. Hardiman FB Fransisco. Yogyakarta: Buku Baik

11. Yin RK. 1989. Case Study Research Design dan Method, COSMOS Corporation

12. Yuliasari I et al. 2016. Community Radio Based On Local Wisdom As Information Media In Special Region Of Yogyakarta. I Internatinal Journal of Research in Social Science. Vol.VII: 35-43 